\title{
Studies on Chromate Removal by Chromium-Resistant Bacillus sp. Isolated from Tannery Effluent
}

\section{Manoj Kumar Chaturvedi}

Nano Mission, Department of Science and Technology, Government of India, Technology Bhawan, India.

Email: mkchat@rediffmail.com

Received September $23^{\text {rd }}, 2010$; revised November $10^{\text {th }}, 2010$; accepted December $26^{\text {th }}, 2010$.

\begin{abstract}
A chromate-removing strain was isolated from spent chrome effluent and identified as Bacillus circulans strain MN1. The isolated strain was studied for resistance to $\mathrm{Cr}(V I)$ and its ability to remove $\mathrm{Cr}(V I)$. The strain was found to tolerate $\mathrm{Cr}(V I)$ concentration as high as $4500 \mathrm{mg} / \mathrm{L}$, but the cells growth was heavily influenced when initial Cr (VI) concentration was increased between $1110 \mathrm{mg} / \mathrm{L}$ and $4500 \mathrm{mg} / \mathrm{L}$ while $\operatorname{Cr}(V I)$ at $500 \mathrm{mg} / \mathrm{L}$ to $1110 \mathrm{mg} / \mathrm{L} \mathrm{did} \mathrm{not} \mathrm{suppressed}$ the cells growth. The experiments also demonstrated that the cells removed toxic $\mathrm{Cr}(\mathrm{VI})$ more efficiently at $30^{\circ} \mathrm{C}$ compared with that at $25^{\circ} \mathrm{C}$ and $35^{\circ} \mathrm{C}$. The optimum initial $\mathrm{pH}$ for $\mathrm{Cr}(\mathrm{VI})$ removal was 5.6 and final $\mathrm{pH}$ values of 5.1-5.6 were observed for initial $\mathrm{pH}$ 5.2-5.7.
\end{abstract}

Keywords: Bacillus sp., Bioremediation, Cr (VI) Removal, Tannery Effluent

\section{Introduction}

Hexavalent chromium is recognized as one of the most dangerous environmental pollutant due to its ability to cause mutations and cancer in humans. Chromium is a heavy metal with large industrial application, such as in textile dyeing, chemicals and pigments production, wood preservation, tanning activity and electroplating for surface treatment [1]. The extensive application of chromium in a variety of industries and disposal of the chrome laded wastewaters without appropriate treatment pose a great threat to the environmental and human health. Chromium generally exists in two stable oxidation states, trivalent chromium and hexavalent chromium. The trivalent chromium is less toxic and mobile, while hexavalent chromium is easily soluble and 100 -fold more toxic than trivalent chromium. The hexavalent form of chromium, usually present in form of chromate $\left(\mathrm{CrO}_{4}^{-}\right)$ and dichromate $\left(\mathrm{Cr}_{2} \mathrm{O}_{7}{ }^{-}\right)$possesses significant higher levels of toxicity than other valence states [2]. Chromate $\left(\mathrm{CrO}_{4}^{-}\right)$is a strong oxidizing agent that is reduced intracellularly to $\mathrm{Cr}^{5+}$ and reacts with nucleic acids and other cell components to produce mutagenic and carcinogenic effect on biological systems [3]. Accordingly, the decontamination of hexavalent chromium is of great importance.
The conventional methods for heavy metals removal from industrial effluents are precipitation, coagulation, ion exchange, cementation, elctro-dialysis, elctro-winning, elctro-coagulation, reverse osmosis [4]; evaporation, solvent extraction and membrane separation [1]. These processes are expensive and present some technological problems, mainly when applied to diluted metal solution. Biosorption is a process in which certain types of biomasses, viable or dead, may bind and concentrate heavy metals from aqueous solutions [5]. Microorganisms have a high surface area-to-volume ratio because of their small size and therefore, they can provide a large contact interface, which would interact with metals from the surrounding environment [6]. The structural polymers in the bacteria cell provide acidic functional groups like carboxyl, phosphoryl and amino groups that are directly responsible for reactivity of the bacterial cells [7]. All the surfaces of the bacteria are intrinsically reactive towards dissolved metals, despite the different surface formats between different types of bacteria. It has been proved that, in some cases, growing cells are able to remove metals continuously through internal detoxification mechanisms [8].

Microbial removal of toxic hexavalent chromium has practical importance, because biological strategies pro- 
vide green technology that is cost-effective [9]. Isolation and identification of chromium (VI)-resistant and chromium (VI)-reducing strain are fundamentally significant. $\mathrm{Cr}$ (VI) reduction by different microorganisms has been well documented in different studies [10]. In previous researches, many species of microorganisms, including strain of Pseudomonas [11-13]; Escherichia [14,15]; Enterobacter [16-18]; Bacillus [19-21]; Shewanella [22,23]; have been found to be able to reduce $\mathrm{Cr}$ (VI). It is reported that a chrome-resistant $P$. ambigua strain GI reduced chromate anaerobically [24]. The mechanisms by which these microorganisms reduce $\mathrm{Cr}$ (VI) are variable and are species dependent. Some species use Cr (VI) as the final electron acceptor in the respiratory chain $[25,26]$ whiles in some other strains certain soluble enzymes are responsible for reduction of $\mathrm{Cr}$ (VI) to $\mathrm{Cr}$ (III) [20,14,27, 28]. Reduced trivalent chromium is less toxic than hexavalent chromium and it readily precipitates, forming less soluble chromium hydroxide at normal $\mathrm{pH}$. Therefore these bacterial ability to reduce chromate would be useful not only for detoxification but for removal of total chromium from wastewaters. Microbial chromate reduction becomes a bit complicated as a result of the effect of environmental conditions under which microbial Cr (VI) reduction proceeds, thus, determining the optimum conditions is also quite important for the maximum conversion of chromium (VI). The ability of these microbial strains for detoxification and removal of total chromium from wastewaters can be exploited the best under optimum condition of controlling parameters.

The aim of present study is to isolate and identify the chromate-resistant and chromate removing bacteria from the spent chrome effluent where the hexavalent chromium level is quite high, research the bacterial chromate removal, and determine the preferable conditions for bacterial chromate removal. This paper describes the effect of temperature, initial chromate concentration on $\mathrm{Cr}$ (VI) removal and resistance and growth of the isolated strain. The paper also study about the variation in $\mathrm{pH}$.

\section{Material and Methods}

\subsection{Bacterial Strain and Cultivation Conditions}

Chromate-resistant bacterium was isolated from spent chrome effluent containing high level of chromium. The spent chrome-effluent was obtained from a local tannery in Kanpur, U.P. India. For isolation and enumeration, sample of spent chrome effluent was serially diluted to obtain the serial 9-fold dilution sample suspension at a dilution of $10^{-7}$. One milliliter aliquots were withdrawn from $10^{-7}$ sample suspension dilution and dropped respectively to the sterilized culture plates, followed by pouring nutrient agar media. The media did not contain
$\mathrm{Cr}$ (IV) as the spent chrome-effluent already contained high concentration of chromate and allowed the growth of chromate-resistant microbial strains, only. The plates were incubated at $30^{\circ} \mathrm{C}$ for 24 hours. Colonies were than streaked on separate nutrient agar plate, incubated at $30^{\circ} \mathrm{C}$ for 24 hours. Finally the bacterium was inoculated from the plate onto agar slant and stored at $4^{\circ} \mathrm{C}$ until needed for further experiments. The agar medium consisted of beef extract $(3.0 \mathrm{~g})$, peptone $(5.0 \mathrm{~g})$, glucose $(1.0 \mathrm{~g}) \mathrm{NaCl}(2.5 \mathrm{~g})$, agar $(20.0 \mathrm{~g})$ in 1 liter distilled water. The $\mathrm{pH}$ value of the medium was adjusted to 7.0 by adding aliquot of either $10 \%(\mathrm{w} / \mathrm{v}) \mathrm{HCL}$ or $10 \%(\mathrm{w} / \mathrm{v})$ $\mathrm{NaOH}$.

The operations of gram-staining and morphological studies followed by biochemical tests were first performed for preliminary characterization of the isolate before the isolate was identified by Bergeys' Methods of Determinative Bacteriology [29]. The present bacterial strain has been preserved with Microbial Type Culture Collection and Gene Bank (MTCC) at the Institute of Microbial Technology (C.S.I.R.), Sector 39-A, Chandigarh-160 036, India, under accession number MTCC 3918.

\subsection{Growth Media and Culture Conditions}

The isolated strain was grown under microaerophilic conditions at $30^{\circ} \mathrm{C}$ for 24 hours in sterilized nutrient broth containing in gram per liter distilled water glucose, $1.0 \mathrm{~g}$; peptone, $5.0 \mathrm{~g}$; and beef extract, $3.0 \mathrm{~g}$. Adjustment of $\mathrm{pH}$ to $6.8 \pm 0.1$ was made by adding aliquots of either $\mathrm{HCl}$ or $\mathrm{NaOH}$. Suspension for inoculums was obtained by growing the isolated strain $\mathrm{MN} 1$, in $5 \mathrm{~mL}$ sterilized nutrient broth, incubated at $30^{\circ} \mathrm{C}$ for 24 hours under microaerophilic condition. Higher volumes of inoculums were obtained by inoculating pre-sterilized nutrient broth with inoculums having one-tenth volume of required final volume of inoculums and incubated at $30^{\circ} \mathrm{C}$ for 24 hours.

\subsection{Cr (VI) Removal Experiments}

The isolated strain was enriched by transferring one loop of cells from the agar slant to $100 \mathrm{~mL}$ of previously sterilized liquid nutrient medium in $250 \mathrm{~mL}$ flasks and incubated at $30^{\circ} \mathrm{C}$ for 24 hours. The liquid medium contained the same components described as above in agar medium except agar and the $\mathrm{pH}$ value was adjusted to 7.0 in the same way as mentioned above. The media were autoclaved at $120^{\circ} \mathrm{C}$ for 20 minutes before used in $\mathrm{Cr}$ (VI) removal experiments. The $50 \mathrm{~mL}$ flasks containing varying concentrations $(500 \mathrm{mg} / \mathrm{L}$ to $4500 \mathrm{mg} / \mathrm{L})$ of $\mathrm{Cr}(\mathrm{VI})$ as $\mathrm{K}_{2} \mathrm{Cr}_{2} \mathrm{O}_{7}$ were inoculated with $20 \mathrm{~mL}$ of enriched cells suspension and incubated under the same conditions described above. The liquid media was supplemented with 
$1000 \mathrm{mg} / \mathrm{L}$ glucose as the electron donors. All of the stock solutions were autoclaved as described above before used in Cr (VI) removal experiments. The experiments were performed in triplicate. Cells suspension volume, growth phase and $\mathrm{Cr}$ (VI) reduction conditions were the same in all the sets. Incubation temperature was varied at $25^{\circ} \mathrm{C}, 30^{\circ} \mathrm{C}$ and $35^{\circ} \mathrm{C}$ to study the effect of temperature on $\mathrm{Cr}$ (VI) removal. The cells suspension used was $20 \mathrm{~mL}$ and was the logarithmic phase culture of isolated strain (MLVSS, $3000 \mathrm{mg} / \mathrm{L}$ ) prepared in nutrient broth. A layer of paraffin was used to maintain microaerophilic conditions.

\subsection{Analytical Methods}

Samples were drawn and filtered using $0.45 \mu \mathrm{m}$ filter paper (47 mm, Cat. No. HAWP 04700 Millipore India Pvt. Ltd.). The chromate concentration, growth of the bacterial strain and $\mathrm{pH}$ was evaluated at $0 \mathrm{~h}$ and $24 \mathrm{~h}$. $\mathrm{Cr}$ (VI) concentration in supernatant was determined colorimeterically using diphynelcarbazide reagent in acid solution with a spectrophotometer (SpectronicR Geneys TM 2) following standard methods [30]. The Cr (IV) determination analysis involved dilution of the initial $\mathrm{Cr}$ (IV) concentrations to the level sensitive enough to be determined by employing colorimetric method. Final $\mathrm{Cr}$ (IV) values were obtained by incorporating dilution factor into the calculations. Bacterial cell density of the liquid culture was determined as MLVSS following Standard methods [30]. The growth of the isolated strain in experimental sets containing varying concentration of the chromate $(500 \mathrm{mg} / \mathrm{L}$ to $4500 \mathrm{mg} / \mathrm{L})$ as potassium dichromate indicated the chromate resistance of the isolated strain. The $\mathrm{pH}$ was determined using a $\mathrm{pH}$ meter (EUTECH Cyber Scan ISO 9001 Certified) with an accuracy of \pm 0.01 . The $\mathrm{pH}$ meter was calibrated with standard $\mathrm{pH}$ meter. All the chemicals used in the present study were of analytic grade when available.

\section{Results and Discussion}

\subsection{Identification of the Strain}

The tests of gram-reaction showed that the strain is gram-positive. In the following operations the strain was identified by Bergeys' Methods of Determinative Bacteriology [29]. The strain was found to belong to genus Bacillus. This may imply that Bacillus sp. probably have become dominant strains in the high level of Cr (VI)containing spent chrome effluent and other bacteria which cannot tolerate the toxicity of the Cr (VI) are excluded from the spent chrome effluent because of the selective pressure. The biochemical characteristics of the isolated strain are shown in Table 1. The strain is designated as Bacillus circulans MN1. The bacterium of strain
Bacillus circulans MN1 was eventually used in the following $\mathrm{Cr}(\mathrm{VI})$ reduction experiments. A variety of microorganisms with $\mathrm{Cr}(\mathrm{VI})$-resistant and $\mathrm{Cr}$ (VI)-reducing ability have been isolated from chrome-contaminated environment [12,20,31-33].

\subsection{Effect of Temperature and Cr (VI) on the Cells Growth}

The effect of $\mathrm{Cr}$ (VI) on the growth of $\mathrm{Cr}$ (VI)-resistant strain Bacillus circulans MN1 was evaluated at $25^{\circ} \mathrm{C}$, $30^{\circ} \mathrm{C}$, and $35^{\circ} \mathrm{C}$. Figure 1 shows the relationship between growth of the cells and initial $\mathrm{Cr}(\mathrm{VI})$ concentration at the three temperatures. The cells were grown in media supplemented with varying $\mathrm{Cr}(\mathrm{VI})$ concentrations. The biomass concentration $(\mathrm{mg} / \mathrm{L}$, dry wt.) was tested after incubation of $24 \mathrm{~h}$ Initial biomass concentration was constant in all the experimental sets. It was obvious that the growth of the cells was heavily influenced when $\mathrm{Cr}$ (VI)

Table 1. Characteristics of the isolated strain.

\begin{tabular}{llcc}
\hline \multicolumn{1}{c}{ Biochemical Tests } & Results & $\begin{array}{c}\text { Acid production } \\
\text { from carbohydrates }\end{array}$ & Results \\
\hline Growth on MacConkey agar & $(-) \mathrm{ve}$ & Adonitol & $(-) \mathrm{ve}$ \\
Indole test & $(-) \mathrm{ve}$ & Arabinose & $(+) \mathrm{ve}$ \\
Methyle Red test & $(+) \mathrm{ve}$ & Cellobiose & $(+) \mathrm{ve}$ \\
Voges Proskaure test & $(-) \mathrm{ve}$ & Dextrose & $(+) \mathrm{ve}$ \\
Citrate Utilization & $(-) \mathrm{ve}$ & Dulcitol & $(+) \mathrm{ve}$ \\
Casein hydrolysis & $(+) \mathrm{ve}$ & Fructose & $(-) \mathrm{ve}$ \\
Strach hydrolysis & $(+) \mathrm{ve}$ & Galactose & $(+) \mathrm{ve}$ \\
Urea hydrolysis & $(-) \mathrm{ve}$ & Inositol & $(-) \mathrm{ve}$ \\
ONPG hydrolysis & $(-) \mathrm{ve}$ & Inulin & $(-) \mathrm{ve}$ \\
Nitrate reduction & $(+) \mathrm{ve}$ & Lactose & $(-) \mathrm{ve}$ \\
Nitrite reduction & $(+) \mathrm{ve}$ & Maltose & $(+) \mathrm{ve}$ \\
H2S production & $(-) \mathrm{ve}$ & Mannitol & $(+) \mathrm{ve}$ \\
Cytochrome Oxidase test & $(+) \mathrm{ve}$ & Mannose & $(-) \mathrm{ve}$ \\
Catalase test & $(+) \mathrm{ve}$ & Melibiose & $(-) \mathrm{ve}$ \\
Oxidation/fermentation & F & Raffinose & $(-) \mathrm{ve}$ \\
Gelatine liquefaction & $(+) \mathrm{ve}$ & Rhamnose & $(+) \mathrm{ve}$ \\
Arginine dihydrolase & $(+) \mathrm{ve}$ & Salicin & $(+) \mathrm{ve}$ \\
Lysine decarboxylase & $(+) \mathrm{ve}$ & Sorbitol & $(-) \mathrm{ve}$ \\
Ornithine decaroxylase & $(-) \mathrm{ve}$ & Sucrose & $(+) \mathrm{ve}$ \\
& & Trehalose & $(+) \mathrm{ve}$ \\
& & Xylose & $(+) \mathrm{ve}$ \\
\hline
\end{tabular}

The (-) ve (negative) and $(+)$ ve (positive) results indicated in the Table 1 implies that desired reaction has not taken place/has taken place, respectively. 


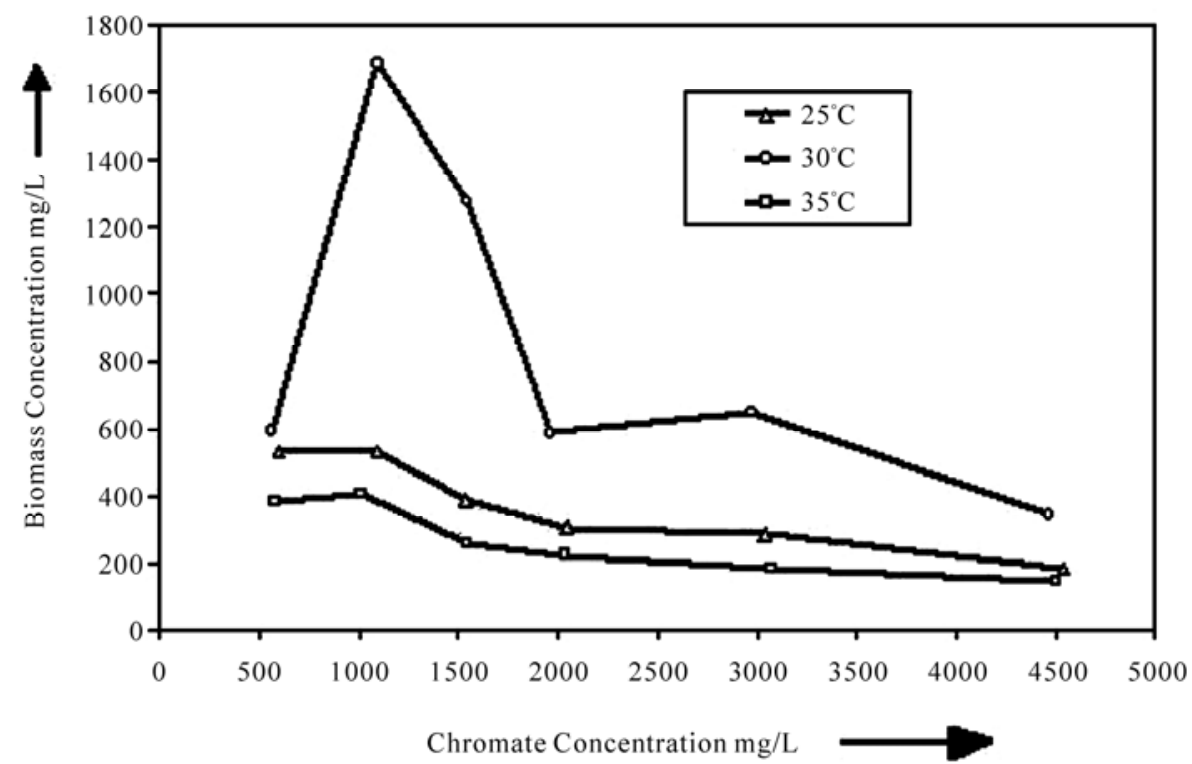

Figure 1. Effect of initial $\mathrm{Cr}$ (VI) concentration on growth of Bacillus circulans $\mathrm{MN1}$ at $25^{\circ} \mathrm{C}, 30^{\circ} \mathrm{C}$ and $35^{\circ} \mathrm{C}$ respectively.

concentration was added up to $4500 \mathrm{mg} / \mathrm{L}$, at all the three temperatures. The highest growth of $\mathrm{Cr}$ (VI)-resistant cells (MLVSS, $1780 \mathrm{mg} / \mathrm{L}$ ) was observed at $30^{\circ} \mathrm{C}$ at initial $\mathrm{Cr}(\mathrm{VI})$ concentration of $1110 \mathrm{mg} / \mathrm{L}$. The result indicated that the isolated strain Bacillus circulans MN1 could tolerate $\mathrm{Cr}$ (IV) concentration as high as 1110 $\mathrm{mg} / \mathrm{L}$. It was observed that growth of cells was heavily influenced when initial $\mathrm{Cr}$ (VI) concentration was increased beyond $1110 \mathrm{mg} / \mathrm{L}$ and $4500 \mathrm{mg} / \mathrm{L}$ while $\mathrm{Cr}$ (VI) at $500 \mathrm{mg} / \mathrm{L}$ to $1110 \mathrm{mg} / \mathrm{L}$ did not suppressed the cells growth. This indicated the greater toxicity of $\mathrm{Cr}$ (VI) to the cells at higher $\mathrm{Cr}(\mathrm{VI})$ concentrations. It is also reported that chromate at $52 \mathrm{mg} / \mathrm{L}$ significantly affected cells growth of Bacillus subtilis and the cells failed to grow and reduce chromate at $104 \mathrm{mg} / \mathrm{L}$ chromate [19].

The tolerance of $\mathrm{Cr}$ (VI)-resistant cells decreased at $25^{\circ} \mathrm{C}$ for all initial $\mathrm{Cr}$ (VI) concentration studied. The cells exhibited minimum tolerance toward $\mathrm{Cr}$ (VI) at $35^{\circ} \mathrm{C}$ for all initial $\mathrm{Cr}(\mathrm{VI})$ concentration studied.

\subsection{Effect of Temperature and Cr (VI) on Cr (VI) Removal}

Temperature is an important factor that has effect on microbial Cr (VI) removal. Cr (VI) removal by the strain Bacillus circulans MN1, was evaluated under three different temperature: $25^{\circ} \mathrm{C}, 30^{\circ} \mathrm{C}$, and $35^{\circ} \mathrm{C}$. The results are presented in Figure 2. The final $\mathrm{Cr}$ (VI) concentration was tested after incubation of $24 \mathrm{~h}$. Initial biomass concentration was constant in all the experimental sets. $\mathrm{Cr}$ (VI) was removed effectively $(71.4 \%)$ at $30^{\circ} \mathrm{C}$ for initial $\mathrm{Cr}$ (VI) concentration of $1100 \mathrm{mg} / \mathrm{L}$, after 24 hours. The $\mathrm{Cr}$ (IV) concentration determined in experimental set, after completion of incubation period was subtracted from the initial chromate concentration in the experimental set and divided by 100 , to arrive at the percent chromate removal by the strain Bacillus circulans MN1. The $\mathrm{Cr}$ (VI) removal by the cells was severely affected at $35^{\circ} \mathrm{C}$ and $25^{\circ} \mathrm{C}$ temperature. This indicates that strain removed $\mathrm{Cr}$ (VI) better at $30^{\circ} \mathrm{C}$ compared with that at $35^{\circ} \mathrm{C}$ and $25^{\circ} \mathrm{C}$. The initial $\mathrm{Cr}$ (VI) concentration above $1100 \mathrm{mg} / \mathrm{L}$ affected the $\mathrm{Cr}$ (VI) removal ability of the strain Bacillus circulans $\mathrm{MN} 1$, at all temperatures i.e. $25^{\circ} \mathrm{C}, 30^{\circ} \mathrm{C}$ and $35^{\circ} \mathrm{C}$. Chromium (VI) bacterial resistance up to $2500 \mathrm{mg} / \mathrm{L}$ has been reported by Camargo [31]. Chromium (VI) bacterial resistance above 2500 $\mathrm{mg} / \mathrm{L}$ has only been reported by Shakoori [32].

\subsection{Variation of $\mathbf{p H}$}

Initial culture $\mathrm{pH}$ of the medium was considered as a factor for growth and $\mathrm{Cr}$ (VI) removal by strain Bacillus circulans MN1. This study tested the variation of $\mathrm{pH}$ in every experimental set and data are listed in Table 2. In general the $\mathrm{pH}$ value has the trend of being decreased. This variation may be caused by the metabolites secreted by cells.

The strain Bacillus circulans MN1 exhibited maximum $\mathrm{Cr}$ (VI) resistant at initial $\mathrm{pH} 5.6$ at $25^{\circ} \mathrm{C}$ (MLVSS, $550 \mathrm{mg} / \mathrm{L}$ ); $30^{\circ} \mathrm{C}$ (MLVSS, $1781 \mathrm{mg} / \mathrm{L}$ ) and $35^{\circ} \mathrm{C}$ (MLVSS, $410 \mathrm{mg} / \mathrm{L}$ ) for initial $\mathrm{Cr}$ (VI) concentration of $1110 \mathrm{mg} / \mathrm{L}$. Optimum Cr (VI) reduction at varying temperature was directly related to the optimum $\mathrm{pH}$ for growth of the strain Bacillus circulans MN1. Value for pH of 5.4 and 5.5 restricted bacterial growth and $\mathrm{Cr}$ (VI) removal at the temperature studied (data not shown). 


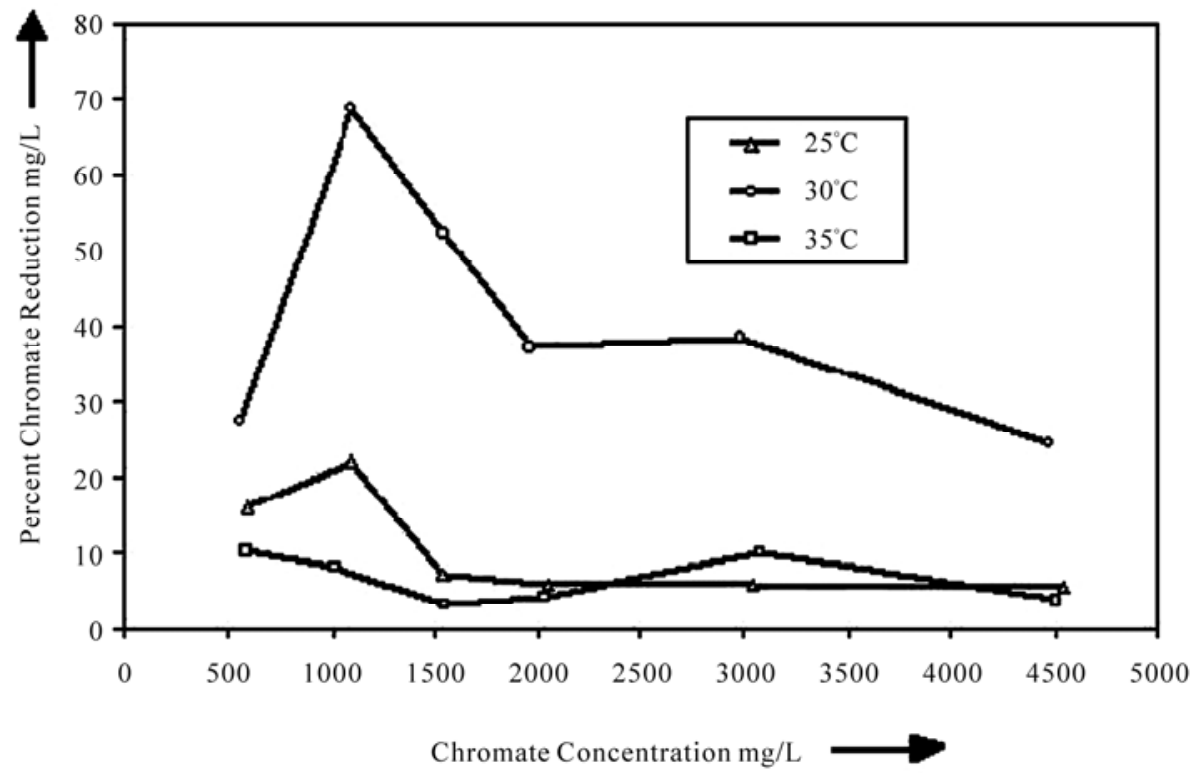

Figure 2. Effect of initial $\mathrm{Cr}$ (VI) concentration on $\mathrm{Cr}$ (VI) removal by Bacillus circulans $\mathrm{MN1}$ at $25^{\circ} \mathrm{C}, 30^{\circ} \mathrm{C}$ and $35^{\circ} \mathrm{C}$ respectively.

Table 2. Variation of $\mathrm{pH}$ in the medium used for $\mathrm{Cr}$ (VI) removal by Bacillus circulans MN1.

\begin{tabular}{|c|c|c|c|c|}
\hline \multirow{2}{*}{$\begin{array}{c}\text { Initial } \mathrm{Cr}(\mathrm{VI}) \\
\text { Con., mg/L }\end{array}$} & \multirow{2}{*}{$\begin{array}{l}\text { Initial } \mathrm{pH} \\
\text { value }^{\mathrm{a}}\end{array}$} & \multicolumn{3}{|c|}{$\begin{array}{c}\mathrm{pH} \text { value after } 24 \mathrm{~h} \text { at varying } \\
\text { temperature }\end{array}$} \\
\hline & & $25^{\circ} \mathrm{C}$ & $30^{\circ} \mathrm{C}$ & $35^{\circ} \mathrm{C}$ \\
\hline 550 & 5.7 & 5.6 & 5.6 & 5.6 \\
\hline 1100 & 5.6 & 5.5 & 5.5 & 5.5 \\
\hline 1550 & 5.5 & 5.4 & 5.4 & 5.4 \\
\hline 2000 & 5.4 & 5.3 & 5.3 & 5.3 \\
\hline 3000 & 5.2 & 5.2 & 5.2 & 5.3 \\
\hline 4500 & 5.2 & 5.1 & 5.1 & 5.1 \\
\hline
\end{tabular}

${ }^{\mathrm{a}}$ Initial $\mathrm{pH}$ values of the replicates were adjusted to be identical.

Many other researchers reported the optimum $\mathrm{pH}$ value for bacterial $\mathrm{Cr}(\mathrm{VI})$ reduction but not the optimum initial $\mathrm{pH}$ value. It is reported that the optimum $\mathrm{pH}$ was 9 for $\mathrm{Cr}$ (VI) reduction by gram-negative bacterium [32] but it was found that the optimum $\mathrm{pH}$ was 7 in case of Pseudomonas aeruginosa and Bacillus coagulans [13,20,21]. The difference in optimum $\mathrm{pH}$ value suggests that $\mathrm{pH}$ modification is important for different cultures to achieve the maximum $\mathrm{Cr}$ (VI) reduction in the bioremediation of chromate. The $\mathrm{pH}$ value is an important index reflecting the microbial activity. Evaluation of $\mathrm{pH}$ variation in the course of bacterial $\mathrm{Cr}(\mathrm{VI})$ reduction is helpful for understanding the mechanisms of bacterial $\mathrm{Cr}(\mathrm{VI})$ reduction.

\section{Conclusions}

The bacterium isolated from spent chrome effluent was capable of $\mathrm{Cr}$ (VI) removal. The isolated strain was identified as species Bacillus circulans MN1 and it was used further in $\mathrm{Cr}$ (VI) removal experiments, under microaerophilic conditions.

The cells removed toxic $\mathrm{Cr}$ (VI) more efficiently at $30^{\circ} \mathrm{C}$ when compared with that at $25^{\circ} \mathrm{C}$ and $35^{\circ} \mathrm{C}$. The optimum initial $\mathrm{pH}$ was 5.6. The maximum chromate removal $(71.4 \%)$ at initial chromate concentration of $1110 \mathrm{mg} / \mathrm{L}$ at $30^{\circ} \mathrm{C}$ was achieved during 24 hours of incubation period. However, the growth of the bacterium strain Bacillus circulans MN1, was significantly affected at higher chromate concentration varying from 2000 $\mathrm{mg} / \mathrm{L}$ to $4500 \mathrm{mg} / \mathrm{L}$ at $25^{\circ} \mathrm{C}, 30^{\circ} \mathrm{C}$ and $35^{\circ} \mathrm{C}$. The strain Bacillus circulans MN1, tolerated Cr (VI) over a wide concentration range (500-4500 mg/l).

This result suggests that controlling temperature would be critical for maintaining the bacterial processes for chromate removal. High initial concentrations of the chromate were toxic to the cells. Hence it is imperative that bacterial ability to remove chromate can be achieved by increasing their resistance to chromate. Further researches will be conducted on the mechanisms by which the bacteria remove $\mathrm{Cr}(\mathrm{VI})$.

\section{REFERENCES}

[1] A. Agrawal, V. Kumar and B. D. Pandy, "Remediation Options for the Treatment of Electroplating and Leather Tanning Effluent Containing Chromium - a Review," 
Mineral Processing and Extractive Metallurgy Review, Vol. 27, No. 2, 2006, pp. 99-130. doi: $10.1080 / 08827500600563319$

[2] M. Jr. Horsfall, F. Ogban and E. E. Akporhonor, "Sorption of Chromium (VI) from Aqueous Solution by Cassava (Manihot Sculenta CRANZ) Waste Biomass," Chemistry and Biodiversity, Vol. 3, No. 2, 2006, pp. 161-173. doi:10.1002/cbdv.200690019

[3] J. McLean and T. J. Beveridge, "Chromate Reduction by Pseudomonas Isolated from a Site Contaminated with Chromated Copper Arsenate," Applied and Environment Microbiology, Vol. 67, No. 3, 2001, pp. 1076-1084. doi:10.1128/AEM.67.3.1076-1084.2001

[4] S. S. Ahluwalia and D. Goyal, "Microbial and Plant Derived Biomass for Removal of Heavy Metals from Wastewater," Bioresource Technology, Vol. 98, No. 12, 2007, pp. 2243-2257. doi:10.1016/j.biortech.2005.12.006

[5] G. Naja and B. Volesky, "Behavior of Mass Transfer Zone in a Biosorption Column," Environmental Science and Technology, Vol. 40, No. 12, 2006, pp. 3996-4003. doi:10.1021/es051542p

[6] A. I. Zouboulis, M. X. Loukidou and K. A. Matis, "Biosorption of Toxic Metals from Aqueous Solutions by Bacteria Strain Isolated from Metal Polluted Soils," Process Biochemistry, Vol. 39, No. 8, 2004, pp. 909-916. doi:10.1016/S0032-9592(03)00200-0

[7] E. Kulczycki, F. G. Ferris and D. Fortin, "Impact of Cell Wall Structure on the Behavior of Bacterial Cells as Sorbent of Cadmium and Lead," Geomicrobiology Journal, Vol. 19, No. 6, 2002, pp. 553-556. doi:10.1080/01490450290098586

[8] B. Godlewska-Zylkiewicz, "Microorganisms in Inorganic Chemical Analysis," Analytical and Bioanalytical Chemistry, Vol. 384, 2006, pp. 114-123. doi:10.1007/s00216-005-0142-2

[9] A. Ganguli and A. K. Tripathi, "Bioremadiation of Toxic Chromate from Electroplating Effluent by Chrome Reducing Pseudomonas Aeruginosa A2Chr in Two Bioreactors," Applied Microbiology and Biotechnology, Vol. 58, No. 3, 2002, pp. 416-420. doi:10.1007/s00253-001-0871-x

[10] D. R. Lovely and E. J. P. Phillips, "Reduction of Chromate by Desulfovibrio Vulgaris and Its C3 Cytochrome," Applied and Environment Microbiology, Vol. 60, No. 2, 1994, pp. 726-728.

[11] V. V. Konovalova, G. M. Dmytrenko, R. R. Nigmatullin, M. T. Bryk and P. I. Gvozdyak, "Chromium(VI) Reduction in Membrane Bioreactor with Immobilized Psedomonas Cells," Enzyme and Microbial Technology, Vol. 33, No. 7, 2003, pp. 899-907. doi:10.1016/S0141-0229(03)00204-7

[12] A. Ganguli and A. K. Tripathi, "Survival and Chrome Reducing Ability of Pseudomonas Aeruginosa in Industrial Effluents," Letters in Applied Microbiology, Vol. 28, No. 1, 1999, pp. 76-80. doi:10.1046/j.1365-2672.1999.00457.x
[13] Y. G. Liu, W. H. Xu , G. M. Zeng, C. F. Tang and C. F. $\mathrm{Li}$, "Experimental Study on Reduction by Pseudomonas Aeruginosa," Journal of Environmental Sciences, Vol. 16, No. 5, 2004, pp. 797-801.

[14] H. Shen and Y. T. Wang, "Characterization of Enzymatic Reduction of Hexavalent Chromium by Eshcherichia Coli ATCC 33456," Applied and Environment Microbiology, Vol. 59, No. 11, 1993, pp. 3771-3777.

[15] D. F. Ackerley, C. F. Gonzalez, M. Keyhan, R. Blake and A. Matin, "Mechanism of Chromate Reduction by Eshcherichia Coli Protein, Nfsa, and Role of Different Chromate Reductases in Minimizing Oxidative Stress during Chromate Reduction," Environmental Microbiology, Vol. 6, No. 8, 2004, pp. 851-860. doi:10.1111/j.1462-2920.2004.00639.x

[16] H. Ohtake, E. Fujii and K. Toda, "Reduction of Toxic Chromate in Industrial Effluent by Use of Chromate Reducing Strain of Enterobacter Cloacae," Environmental Science and Technology, Vol. 11, 1990, pp. 663-668. doi:10.1080/09593339009384909

[17] M. A. Rege, J. N. Petersen, D. L. Johnstone, C. E. Turick, D. R. Yonge and W. A. Apel, "Bacterial Reduction of Hexavalent Chromium by Enterobacter Cloacae Strain HO1 Grown on Sucrose," Biotechnology letters, Vol.19 No.7, 1997, pp. 691-694. doi:10.1023/A:1018355318821

[18] P. C. Wang, T. Mori, K. Komori, M. Sasatsu, K. Toda and H. Ohtake, "Isolation and Characterization of Enterobacter Cloacae Strain that Reduces Hexavalent Chromium under Anaerobic Conditions," Applied and Environment Microbiology, Vol. 55, No. 7, 1989, pp. 1665-1669.

[19] C. Garbisu, I. Alkorta, M. J. Lama and J. L. Serra, “Aerobic Chromate Reduction by Bacillus Subtilis," Biodegradation, Vol. 9, No. 2, 1998, pp. 133-141. doi:10.1023/A:1008358816529

[20] L. Philip, L. Iyengar and C. Vencobachar, "Cr (VI) Reduction by Bacillus Coagulans Isolated from Contaminated Soils," Journal of Environmental Engineering, Vol. 124, No. 12, 1998, pp. 1165-1170. doi:10.1061/(ASCE)0733-9372(1998)124:12(1165)

[21] Y. T. Wang and C. S. Xiao, "Factors Affecting Hexavalent Chromium Reduction in Pure Culture of Bacteria," Water Research, Vol. 29, No. 11, 1995, pp. 2467-2474. doi:10.1016/0043-1354(95)00093-Z

[22] C. R. Myer, B. P. Carstens, W. E. Antholine and J. M. Myers, "Chromium (VI) Reductase Activity Associated with the Cytoplasmic Membrane of Anaerobically Grown Shewanella Putrefaciens MR-1," Journal of Applied Microbiology, Vol. 88, No. 1, 2000, pp. 98-106. doi:10.1046/j.1365-2672.2000.00910.x

[23] S. Viamajala, B. M. Peyton and J. N. Petersen, "Modelling Chromate Reduction in Shewanella Oneidensis MR-1: Development of a Novel Dual-Enzyme Kinetic Model," Biotechnology and Bioengineering, Vol. 83, No. 7, 2003, pp. 790-797. doi:10.1002/bit.10724 
[24] H. Horitsu, S. Futo, Y. Miyaza, S. Ogais and K. Kawai, "Enzymatic Reduction of Hexavalent Chromium by Hexavalent Chromium Tolerant Pseudomonas Ambigua G-1,” Agric Biol Chems, Vol. 51, 1987, pp. 2417-2420.

[25] L.H. Bopp and H. L. Ehrlich, "Chromate Resistance and Reduction in Pseudomonas Fluorescence Strain LB300," Archives of Microbiology, Vol. 150, No. 5, 1988, pp. 42631. doi:10.1007/BF00422281

[26] P. C. Wang, T. Mori, K. Toda and H. Ohtake, "Membrane-Associated Chromate Activity from Enterobacter Cloacae," Journal of Bacteriology, Vol. 172, No. 3, 1990, pp. 1670-1672.

[27] C. H. Park, M. Keyhan, B. Wielinga, S. Fendorf and A. Matin, "Purification to Homogeneity and Characterization of a Novel Pseudomonas Putida Chromate Reductase," Applied and Environment Microbiology, Vol. 66, No. 5, 2000, pp. 1788-1795. doi:10.1128/AEM.66.5.1788-1795.2000

[28] D. F. Ackerley, C. F. Gonzalez, C. H. Park, R. Blake, M. Keyhan and A. Matin, "Chromate Reducing Properties of Soluble Flavoproteins from Pseudomonas Putida and Eshcherichia Coli," Applied and Environment Microbiology, Vol. 70, No. 2, 2004, pp. 873-882. doi:10.1128/AEM.70.2.873-882.2004

[29] J. G. H Bergey, R. K. Noel and H. A. S. Peter, "Bergeys
Manual of Determinative Bacteriology," $9^{\text {th }}$ Ed., Lippincott Williams \& Wilkins, Baltimore, 1994.

[30] APHA (American Public Health Association), AWWA (American Water Works Association) and WEF (American Environment Federation), "Standard Methods for the Examination of Water and Wastewaters (20 2 th Ed.)," Washington DC, USA, 1998.

[31] F. A. O. Camargo, F. M. Bento and B. C. Okeke, W. T. Frankenberger, "Chromate Reduction by Chromium-ReSistant Bacteria Isolated from Soils Contaminated with Dichromate," Journal of Environmental Quality, Vol. 32, No. 4, 2003, pp. 1228-1233. doi:10.2134/jeq2003.1228

[32] A. R. Shakoori, M. Makhdoom and R. U. Haq, "Hexavalent Chromium Reduction by a Dichromate-Resistant Gram-Positive Bacterium Isolated from Effluents of Tanneries," Applied Microbiology and Biotechnology, Vol. 53, 2005, pp. 348-351. doi: $10.1007 / \mathrm{s} 002530050033$

[33] C. Viti, A. Pace and L. Giovannetti, "Characterization of Cr(VI)-Resistant Bacteria Isolated from Chromium-ConTaminated Soil by Tannery Activity," Current Microbiology, Vol. 46, No. 1, 2003, pp. 1. doi:10.1007/s00284-002-3800-Z 